\title{
PREDICTING FINANCIAL DISTRESS FOR MOBILE TELECOMMUNICATION COMPANIES LISTED IN KUWAIT STOCK EXCHANGE USING ALTMAN'S MODEL
}

\author{
DOI: 10.17261/Pressacademia.2018.933
}

JEFA- V.5-ISS.3-2018(2)-p.242-248

\section{Musaed S. AlAli}

College of Business Studies, Department of Insurance and Banking, Kuwait.The Public Authority for Applied Education and Training (PAAET). ms.alali@paaet.edu.kw, ORCID: 0000-0003-0802-5440

Date Accepted: September 10, 2018

To cite this document

AlAli, M. (2018). Predicting financial distress for mobile telecommunication companies listed in Kuwait Stock Exchange using Altman's model. Journal of Economics, Finance and Accounting (JEFA), V.5(3), p.242-248.

Permemant link to this document: http://doi.org/10.17261/Pressacademia.2018.933

Copyright: Published by PressAcademia and limited licenced re-use rights only.

\section{ABSTRACT}

Purpose- With the bankruptcy of many large companies in recent years especially after the global financial crisis in 2008, the attention to bankruptcy prediction models has increased dramatically. The aim of this study is to examine the financial soundness of the companies listed in the mobile telecommunication sector in the Kuwait stock exchange (KSE).

Methodology- Many bankruptcy models were developed as an early warning systems for any distress a company might face. This paper uses one of the most common models, Altman Z-score model, to examine the likelihood of bankruptcy and the financial soundness of mobile telecommunication companies listed in Kuwait stock exchange market during the period from 2013 to 2016.

Findings- The results showed that out of the three companies operating in Kuwait, only one of them had a healthy financial position while the other two companies are facing financial distress.

Conclusion- The study found that mobile telecommunication companies in Kuwait are facing the risk of bankruptcy due to their negative working capital which makes them vulnerable to any unexpected short-term obligations. As a result, these companies should work to reduce the gap between their current assets and current liabilities.

Keywords: Altman, Z-score, mobile telecommunication sector, Kuwait stock exchange, financial distress, bankruptcy. JEL Codes: G33, H12, M21.

\section{INTRODUCTION}

The telecommunication sector is the second largest sector in the Kuwaiti stock market in term of market capitalization per company with an average market capitalization of KWD 960.7 million. This sector is made of three companies, Zain, Ooredoo, and Viva. The total revenues for the sector in 2016 was KWD 2.073 billion (USD 6.912 billion). Mobile telecommunication company (also known as Zain) is the oldest mobile telecommunication company in Kuwait, it was found in 1983. Zain enjoyed a monopoly over the Kuwaiti market for 16 years from 1983 till 1999. To break the monopoly of Zain over the mobile telecommunication sector, the Kuwaiti government issued a second mobile company license in 1999. The second mobile telecommunication license auction was won by Kuwait Investment Projects Company (KIPCO). But soon after, KIPCO sold their stake in the company to Ooredoo, which is a Qatari owned company, and the new purchaser kept the same name of their mother company. The third mobile telecommunication license auction was won by the Saudi Telecom Company (STC) in the year 2009 and they chose the name Viva for it. Being the second largest sector in the Kuwaiti market means that any shortfall for any of its companies would have a greater effect on the market as whole compared to any other sector. That is why examining the financial soundness of these companies is crucial to maintain the stability of the market and the Kuwaiti economy for that matter.

This study incorporates five sections. The first section covers a brief description of the companies working in the mobile telecommunication sector in Kuwait. In section two, previous literature on the topic of measuring the financial soundness of companies in general and in telecommunication companies in specific is presented. Section three incorporates the data 
and methodology used in this study. In section four the finding are shown and discussed. Finally in section five, the conclusion of the whole work.

\section{LITERATURE REVIEW}

Elloumi and Gueyie (2001) defined a company under a financial distress when having negative net income for two consecutive years. Ward et al. (2006) defined a company under financial distress when having interest coverage ratio of less than one. While others such as Almilia (2006) stated that a company experiencing financial distress is when a company suffers from negative net operating income and is not paying dividends for one consecutive year. Any company facing financial distress should work to address the causes of the problem, otherwise the company might face bankruptcy. Rudianto (2013) defines bankruptcy as a failure in running the business company to achieve its goals. Bankruptcy can be caused by financial failure or economic failure. Financial failure means that a company is unable to pay the company liabilities when mature, even though the total assets more than total liabilities. Economic failure means that a company is unable to cover the company cost. Altman (1968) argued that corporate failure happens in areas where the company management has detected some signs such as the failure to fulfill some obligations but failed to recognize it until it all accumulates and bankruptcy is imminent. Ross et al. (2013) stated that a company is facing bankruptcy when its assets values are equal that of the debts. When this happens, the equity value is equal to zero, and the control of the company is shifted from stockholder bondholder.

Subramanyam and Wild (2013) concluded that Financial analysis using financial ratios is a very useful tool that significantly assists business decision making and distinguishing the weak areas in the company from the strong. Husein and Pambekti (2014) found that financial ratios obtained from the company's financial statement are an efficient way to analyze the soundness of the company and can be used to anticipate future financial difficulties. Almilia (2006) concluded that the results showed that the financial ratios from the income statement, balance sheet and cash flow statement have a significant influence in predicting financial distress. Azadinamin (2013) in his study entitled "The Bankruptcy of Lehman Brothers: Causes of Failure \& Recommendations Going Forward" concluded that the negative cash flow during the three years was the main reason for the bankruptcy of Lehman Brothers. Altman (1968) used financial ratios in his bankruptcy prediction model to produce an early warning system for the companies. Lagkas and Papadopoulos (2014) stated that the accuracy of the Altman z-score model was initially (prior to 1968) estimated to be $72 \%$ in predicting bankruptcy two years before it happens. The revised formula were found to predict bankruptcy one year before the event with $80 \%-90 \%$ accuracy. VenkataRamana, et al. (2012) used Altman Z-score model to examine the financial performance and predict the risk of bankruptcy for the Indian cement companies for the period 2001-2010. They found that KCP Ltd and Kilogram Industries Ltd. experiencing poor financial performance or financial distress. Yet, Dalmia Bharat Ltd. is on the threshold of bankruptcy. This suggests that the use of a model Altman bankruptcy for research is still applicable. Azhar and Ramesh (2017) used Altman's z-score and showed that the majority of companies in India do not have good financial health, thus they point out that there is an urgent need for their administration to examine and reduce the financial difficulty of their companies. Maina and Sakwa (2017) used Altman's z-model to examine the financial soundness of companies in Kenya and they were able to distinguish between companies with good financial position and companies that were in the danger zone. Mahama (2015) investigated the application of Altman's z-score on ten companies listed on the Ghana Stock Exchange (GSE) to determine the level of financial distress. The data used were from year 2007 to 2013 . The results showed that six companies didn't experience financial distress, while two companies experienced financial distress, while the last two companies were facing bankruptcy. AlKhatib and AlBzour (2011) compared the performance of both Altman's and Kida's models in predicting bankruptcy for companies listed in the Jordanian stock exchange during the period 1990-2006. They found that Altman's z-score model had an accuracy rate $94 \%$ compared to $70.2 \%$ for the Kida model in predicting bankruptcy. When it comes to the mobile telecommunication companies, Kpodoh (2009) conducted a study on the three mobile telecommunication companies operating in Ghana. The study covered MTN-Ghana, Millicom-Ghana, and Ghana Telecom for the period 2005-2008. The results showed that MTN-Ghana was the only company that had a z-score of above 2.99 while the other two were in the distress zone. The researcher concluded that the main reason for the low score for both Millicom and Ghana telecom was the high operating costs and recommended that these companies should work in reducing their expenses otherwise they will face bankruptcy.

\section{DATA AND METHODOLOGY}

As for most of the bankruptcy prediction models, Altman (1968) used the Multiple Discriminate Analysis (MDA). The discriminant analysis is a statistical technique that identifies some financial ratios that are considered the most important in influencing the value of an event, and then develops it into a model with a view of making it easier to draw conclusions from an event. Altman's z-score model is based on financial ratios, Husein and Pambekti (2014) concluded that financial ratios founded in the company's financial statement are an efficient way to analyze the soundness of the company and can be used to anticipate future financial difficulties. Altman's z-score is a linear combination of four or five financial ratios, 
weighted by coefficients. The coefficients were estimated by identifying a set of firms which had declared bankruptcy and then collecting a matched sample of firms which had survived, with matching by industry and approximate size (assets).

While there are many Altman z-score models for different types of companies, for example the 5 factor model is used for manufacturing companies and there is a model that is designed for banks, this paper uses Altman 4 factor model to measure the financial stress of the companies. This formula is used for the non-manufacturing and emerging companies. The formula used is as follow;

$Z=6.56 \times 1+3.26 \times 2+6.72 \times 3+1.05 \times 4$

Where;

X1 = working capital (current assets $(C A)$ - current liabilities $(C L)) /$ total assets $(T A)$

$\mathrm{X} 2$ = retained earnings $(\mathrm{RE}) /$ total assets $(\mathrm{TA})$

$\mathrm{X} 3$ = earnings before interest and $\operatorname{tax}(\mathrm{EBIT}) /$ total assets (TA)

$\mathrm{X} 4$ = total book equity $(\mathrm{TE}) /$ total liabilities $(\mathrm{TL})$

The results obtained from the model is then compared to a benchmark that is set to determine the financial soundness of the company. The criteria used to interpret the Z-score model is;

- Safe Zone if Z-score > 2.99 (risk free)

- Gray Zone if $1.81 \leq$ Z-score $\leq 2.99$ (at risk)

- Distress Zone if Z-score $<1.81$ (bankruptcy)

The data used in this paper were obtained from the annual reports of the mobile telecommunication companies under study. By looking at table 1. it can be seen, in the asset side of the balance sheet, that Zain is the largest company in terms of both total assets and current assets almost double the size of Oredoo, the second largest company. The same story can be seen in the liability side where Zain had the highest total and current liabilities out of the three companies. From the shareholders equity side, the story is a bit different where it can be seen that Oredoo had the highest retained earnings followed by Zain. While looking at the paid-up capital, it can be seen that Zain has a paid-up capital that is almost eight times larger than the other two companies. In the income statement side, Zain is by far the highest company in terms of sales and earnings before interest and tax (EBIT). These big differences can be explained by the age of the companies, with Zain being the first mobile company not only in Kuwait but also in the GCC region. This head start gave Zain the opportunity to build up its assets and create a customer base that is loyal to the company.

Table 1: Altman Z-Score Results

\begin{tabular}{|c|c|c|c|c|c|c|c|c|c|c|c|c|}
\hline \multirow[b]{2}{*}{ (All in 1000 KWD except stock price) } & \multicolumn{4}{|c|}{ Viva } & \multicolumn{4}{|c|}{ Oredoo } & \multicolumn{4}{|c|}{ Zain } \\
\hline & 2013 & 2014 & 2015 & 2016 & 2013 & 2014 & 2015 & 2016 & 2013 & 2014 & 2015 & 2016 \\
\hline Current Assets & 28,719 & 63,903 & 87,194 & 82,229 & 367,255 & 322,746 & 284,767 & 288,471 & 766,394 & 720,724 & 795,137 & 676,520 \\
\hline Current Liabilities & 124,732 & 109,872 & 136,009 & 119,883 & 588,742 & 608,084 & 465,747 & 483,144 & 740,968 & 827,680 & 975,068 & 790,074 \\
\hline Total Assets & 178,990 & 213,962 & 263,099 & 267,392 & $1,641,410$ & $1,547,929$ & $1,407,554$ & $1,389,399$ & $3,096,940$ & $3,277,063$ & $3,495,181$ & $3,091,702$ \\
\hline Total Liabilities & 169,408 & 164,016 & 170,194 & 134,679 & 708,959 & 694,541 & 617,661 & 631,240 & $1,333,738$ & $1,483,094$ & $1,767,091$ & $1,669,220$ \\
\hline Retained Earnings & $-40,358$ & 5 & 33,922 & 65,350 & 622,853 & 601,088 & 589,815 & 579,566 & 509,296 & 512,780 & 510,641 & 571,503 \\
\hline Paid-up Capital & 49,940 & 49,940 & 49,940 & 49,940 & 50,403 & 50,403 & 50,403 & 50,403 & 432,268 & 432,706 & 432,706 & 432,706 \\
\hline Share Market Price (in KWD) & 0.580 & 0.650 & 0.990 & 0.930 & 1.760 & 1.400 & 1.100 & 1.200 & 0.690 & 0.530 & 0.350 & 0.410 \\
\hline Sales & 128,422 & 238,974 & 276,888 & 279,059 & 731,117 & 748,496 & 718,418 & 706,841 & $1,240,035$ & $1,213,229$ & $1,137,547$ & $1,087,774$ \\
\hline EBIT & 24,530 & 41,042 & 45,210 & 41,900 & 126,632 & 76,060 & 48,710 & 72,051 & 319,303 & 314,559 & 253,002 & 237,726 \\
\hline Working Capital & $-96,013$ & $-45,969$ & $-48,815$ & $-37,654$ & $-221,487$ & $-285,338$ & $-180,980$ & $-194,673$ & 25,426 & $-106,956$ & $-179,931$ & $-113,554$ \\
\hline Equity Market Value & 289,652 & 324,610 & 494,406 & 464,442 & 887,093 & 705,642 & 554,433 & 604,836 & $2,982,649$ & $2,293,342$ & $1,514,471$ & $1,774,095$ \\
\hline
\end{tabular}

\section{FINDINGS AND DISCUSSIONS}

This paper is based on data collected from the annual reports of the mobile telecommunication companies listed in the Kuwait stock exchange market for the period spanning from 2013 to 2016 . The annual reports were obtained from the Kuwait stock market website.

By looking at the results in table 2, it can be seen that Viva had the best financial position among all three companies, despite being the last company to enter the market. Zain, on the other hand, had a moderate chance of bankruptcy while Ooredoo was at the bottom with a high chance of being bankrupted. 
Table 2: Altman Z-Score Results

\begin{tabular}{|l|l|l|l|l|l|l|}
\hline \multicolumn{7}{|l|}{ Mobile Telecommunication Companies Listed in KSE Market } \\
\cline { 2 - 7 } & VIVA & OOREDOO & \multicolumn{2}{l|}{ ZAIN } \\
\hline & Z-Score & Bankruptcy Risk & Z-Score & Bankruptcy Risk & Z-Score & Bankruptcy Risk \\
\hline $\mathbf{2 0 1 6}$ & 3.536 & Free & 0.561 & High & 1.186 & Gray \\
\hline $\mathbf{2 0 1 5}$ & 2.318 & Gray & 0.417 & High & 0.794 & High \\
\hline $\mathbf{2 0 1 4}$ & 0.669 & High & 0.276 & High & 1.738 & Gray \\
\hline $\mathbf{2 0 1 3}$ & -2.400 & High & 1.070 & High & 2.773 & Gray \\
\hline
\end{tabular}

$2.99<$ Free, $2.99 \geq$ Gray $\geq 1.18,1.18>$ High bankruptcy risk

Figure 1: Altman Z-Score Results

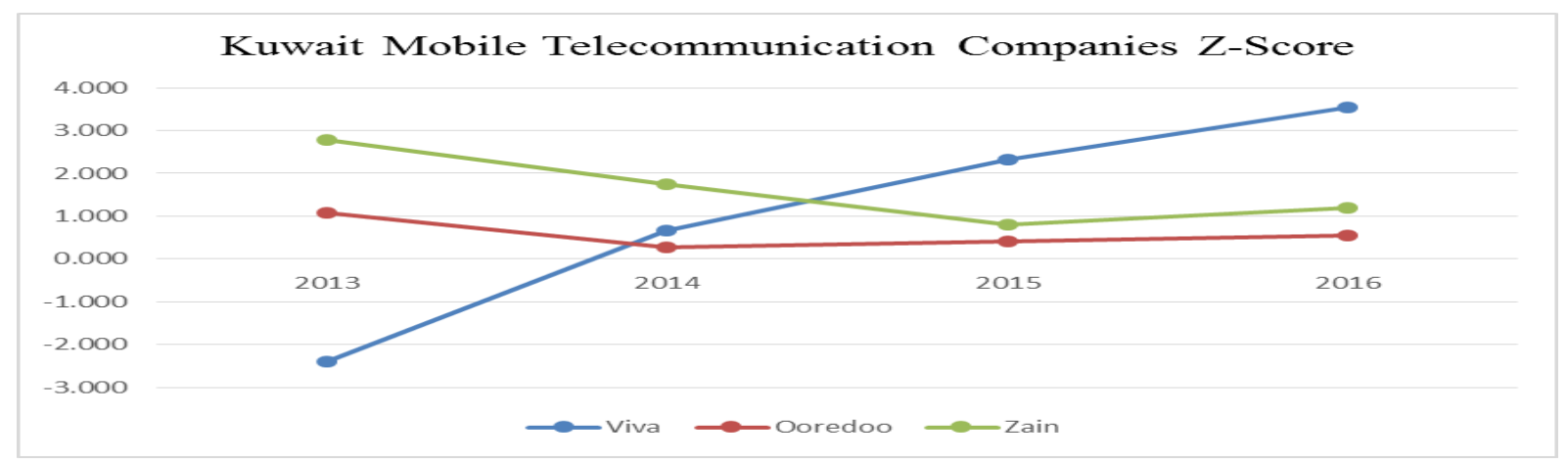

It can also be seen that Viva has shown a constant improvement during the period under study. In 2013, VIVA was the worst company among the three but that situation has changed and by the year 2016 where it was the only company that is in the safe zone. VIVA had a high risk of bankruptcy for the years 2013 and 2014 but that risk was reduced by the year 2015 and in the year 2016 the company was safe from bankruptcy. From table 3, it can be seen that Viva have always struggled in maintaining a positive net working capital meaning that their current liabilities have always exceeded their current assets. When it comes to retained earnings to total assets, it is understandable to have a negative ratio since the company only stared operating late in 2010 and with the setup costs showing their effect on the retained earnings section of the income statement for the past 3 year. But, these negative retained earnings started to diminish once the company's operations started. This would imply an efficient cost control and aggressiveness in perusing income. In the EBIT/total assets ratio, Viva started showing some weakness starting from 2014 onward with the ratio showing a downward trend. When it comes to Viva market capitalization value, it can be see that the price had an upward trend from 2013 till 2015 but the price went slightly down in the year 2016. The reason for the decline in the stock price can be explained by the structure of Viva ownership, where the third license auction was for $25 \%$ of the ownership and as of the end of 2016 Saudi Telecom company (the mother company Viva) owned $51.8 \%$ stake in the company that would imply that buying a larger stake in the company led to the increase in the price in order to obtain control over the company.

Table 3: Viva Financial Ratios Results

\begin{tabular}{|l|l|l|l|l|}
\hline Viva & $\mathbf{2 0 1 3}$ & $\mathbf{2 0 1 4}$ & $\mathbf{2 0 1 5}$ & $\mathbf{2 0 1 6}$ \\
\hline X1 & -0.536 & -0.215 & -0.186 & -0.141 \\
\hline X2 & -0.225 & 0.000 & 0.129 & 0.244 \\
\hline X3 & 0.137 & 0.192 & 0.172 & 0.157 \\
\hline X4 & 1.710 & 1.979 & 2.905 & 3.449 \\
\hline
\end{tabular}

Ooredoo was the worst company in the industry showing a high chance of bankruptcy in every year, it has been showing a downward trend in their z-scores. The company has been facing the risk of bankruptcy since the year 2013, the reason for its survival might be the financial backing of their major shareholder Ooredoo group. Ooredoo group, which the government of the state of Qatar owns $69 \%$ of its shares, holds a $92.17 \%$ stake in Ooredoo Kuwait. Ooredoo has been keeping a negative gap between its current assets and current liabilities for the whole study period as did all other companies in the sector. As for the retained earnings to total assets ratio, Ooredoo held the highest ratio in the sector in all years. But when it comes to the EBIT to total assets ratio the company was the worst in the industry, they were inefficient in getting the most out of their assets when they are compared to its rivals. Again, as for Viva, Ooredoo had a high market 
capitalization to total liabilities which was the result of the takeover price Ooredoo group paid for it. After the takeover the share price started to go down representing the actual value of the company.

Table 4: Ooredoo Financial Ratios Results

\begin{tabular}{|l|l|l|l|l|}
\hline Ooredoo & $\mathbf{2 0 1 3}$ & $\mathbf{2 0 1 4}$ & $\mathbf{2 0 1 5}$ & $\mathbf{2 0 1 6}$ \\
\hline $\mathbf{X 1}$ & -0.135 & -0.184 & -0.129 & -0.140 \\
\hline $\mathbf{X 2}$ & 0.379 & 0.388 & 0.419 & 0.417 \\
\hline $\mathbf{X 3}$ & 0.077 & 0.049 & 0.035 & 0.052 \\
\hline $\mathbf{X} 4$ & 1.251 & 1.016 & 0.898 & 0.958 \\
\hline
\end{tabular}

Figure 2: Viva Stock Price

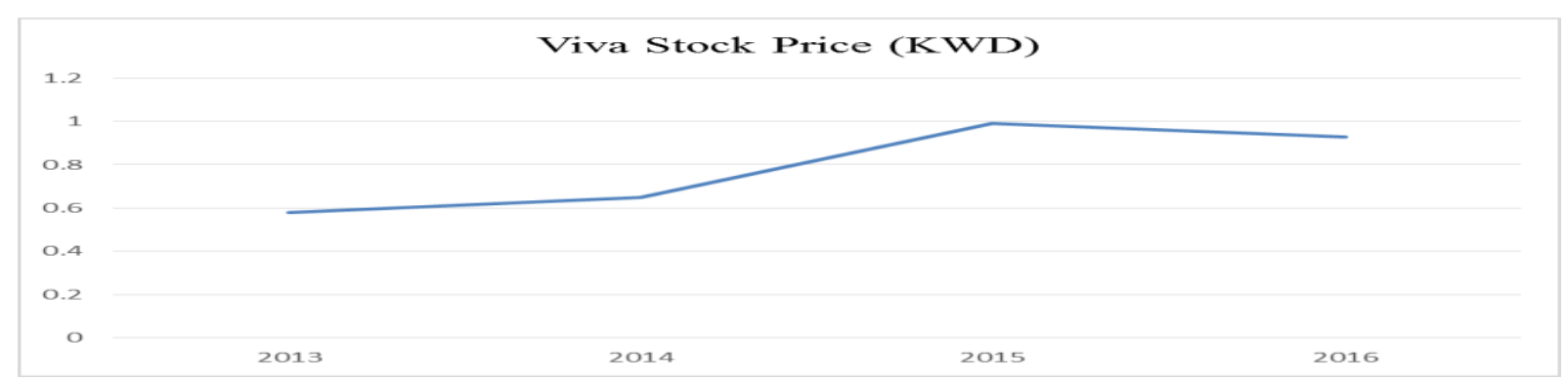

Zain is the first mobile telecommunication company in Kuwait, it was established back in 1983 and enjoyed a monopoly over the mobile telecommunication sector in Kuwait for almost 16 year. By looking at the z-scores of Zain, it can be seen that the Zain did not make the most of their monopoly. Zain showed a high bankruptcy risk in 2015 and they were barely in the gray zone in 2016. Zain still has the backing of the Kuwaiti government since Kuwait Investment Authority (KIA), the investment arm on the Kuwaiti government, owns $24.61 \%$ of the company's shares. Zain was the best performer when it comes to net working capital to total assets averaging -0.028 compared to -0.147 for Ooredoo and -0.269 for Viva. On the flip side, Zain had a declining retained earnings to total assets ratio for the years 2013, 2014, and 2015 but that decline was reversed in 2016. In terms of EBIT to total assets ratio, Zain performed better than Ooredoo but way below Viva. As a result of the declining price of Zain shares, equity market value to total liabilities ratio also showed the same trend, except for the year 2016 and that was because of the offer by Oman Telecommunication Company (Oman Tel) to buy a $21.9 \%$ of the company at a $20 \%$ premium.

Table 5: Zain Financial Ratios Results

\begin{tabular}{|l|l|l|l|l|}
\hline Zain & $\mathbf{2 0 1 3}$ & $\mathbf{2 0 1 4}$ & $\mathbf{2 0 1 5}$ & $\mathbf{2 0 1 6}$ \\
\hline $\mathbf{X 1}$ & 0.008 & -0.033 & -0.051 & -0.037 \\
\hline $\mathbf{X 2}$ & 0.164 & 0.156 & 0.146 & 0.185 \\
\hline $\mathbf{X 3}$ & 0.103 & 0.096 & 0.072 & 0.077 \\
\hline $\mathbf{X} 4$ & 2.236 & 1.546 & 0.857 & 1.063 \\
\hline
\end{tabular}

While literature has shown that Altman's z-score model have a high accuracy rate in predicting the bankruptcy of companies reaching $90 \%$ in some cases, the results obtained in this research showed that none of the companies under study filed for bankruptcy despite being in the high risk of bankruptcy zone for four years as in the case of Ooredoo. One explanation for that is the ownership structure of these companies since all three companies have the backing of deferent governments making them somewhat immune from any financial falls. 


\section{Figure 3: Overall Financial Soundness Position}

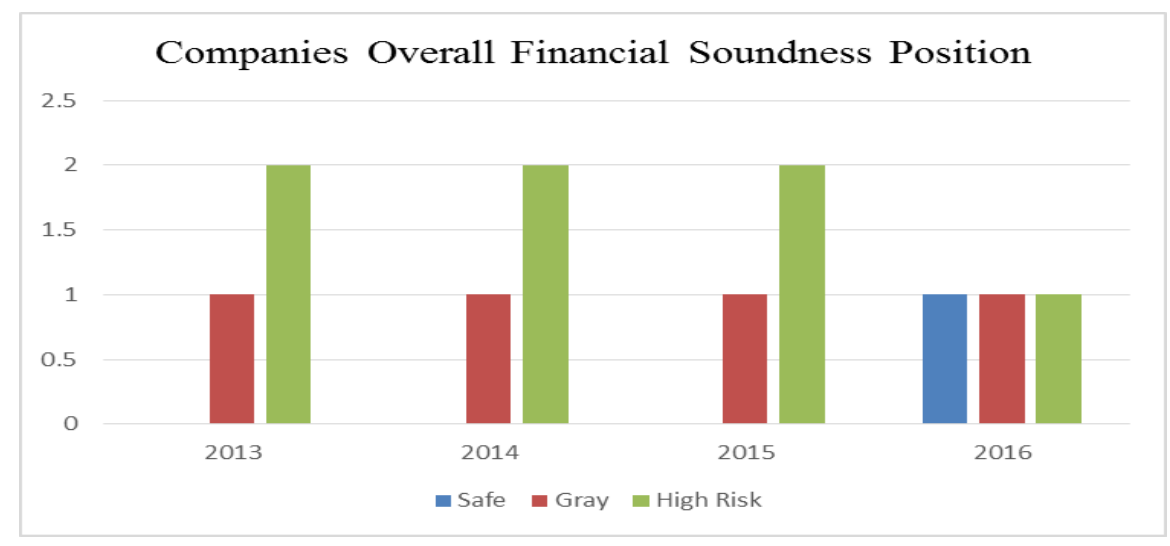

\section{CONCLUSION}

The mobile telecommunication sector is the second largest sector in the Kuwaiti stock market when it comes to market capitalization per company which means that any fall of these companies would have a huge effect on both the stock market and the economy of Kuwait. This makes it crucial for practitioners to monitor the financial soundness of these companies in order to prevent any unfortunate falls. This study showed that only one of the three mobile telecommunications companies operating is Kuwait have a healthy financial position while the other two are facing financial difficulties. The results from this research should send a warning signal for both investors and top management in these companies to re-think about their way in choosing the stocks they invest in, for investors, and the way they conduct their business for the company's top management.

\section{REFERENCES}

AlKhatib, K., AlBzour, A. (2011) Predicting corporate bankruptcy of Jordanian listed companies: using Altman and Kida models. International Journal of Business and Management. Vol. 6 (3), Pages 208-215.

Almilia, L. S. (2006). Prediction of corporate financial distress by multinominal logit analysis. Economic Institute of Perbanas, Surabaya. Indonesia.

Altman, E. (1968). Financial ratios, discriminant analysis and the prediction of corporate bankruptcy. Journal of Finance, Vol. 23, Pages 589609.

Azadinamin, A. (2013). The bankruptcy of Lehman Brothers: causes of failure \& recommendations going forward. Swiss Management Center (SMC) University.

Azhar, S., Ramesh, B. (2017). Predicting financial insolvency of listed power generation/distribution companies in India using Z-score (December 14, 2017). IOSR Journal of Business and Management (IOSR-JBM) (2017). Available at SSRN: https://ssrn.com/abstract=3087896

Elloumi, F., Gueyie, P. J. (2001). Financial distress and corporate governance: an empirical analysis. Corporate Governance, Vol. 1 (1), 15-23.

Husein, M., Pambekti, G. (2014). Precision of models of Altman, Springate, Zmijewski, and Grover for predicting the financial distress. Journal of Economics, Business, and Accounting Ventura, Vol. 17 (3), Pages 405-416, December.

Kpodoh, B. (2009). Bankruptcy and financial distress prediction in the mobile telecom industry: the case of MTN-Ghana, Millicom-Ghana, and Ghana Telecom. Masters Thesis, School of Management - Blekinge Institute of Technology, Spring 2009.

Lagkas, T. D., Papadopoulos, D. (2014). Financial analysis considering distress prediction models of telecommunications companies listed in Athens Stock Exchange: Hellenic telecommunications organization. Forthnet, Hellas Online, International Journal of Decision Sciences, Risk and Management, 5 (4). Pages: 376 - 397, ISSN 1753-7169, https://doi.org/10.1504/IJDSRM.2014.068151

Mahama, M. (2015) Assessing the state of financial distress in listed companies in Ghana: signs, sources, detection, and elimination: a test of Altman's Z-score. European Journal of Business and Management, Vol. 7 (3), 1-11.

Maina, F., Sakwa, M. (2017). Understanding financial distress among listed firms in Nairobi stock exchange: a quantitative approach using the z-score multi-discriminant financial analysis model. University of Agriculture and Technology, Nairobi, Kenya.

Ross, W. J. (2013). Fundamental of corporate finance. McGraw-Hill, Irwin.

Rudianto, A. (2013). Accounting information management for strategic decision making. Erlangga. Jakarta, Indonesia. 
Subramanyam, K. R., Wild, J. (2013). Financial statement analysis. 11 ${ }^{\text {th }}$ edition, N.Y.: McGraw-Hill/Irwin.

VenkataRamana, N., Azash, S., Ramakrishnaiah, K. (2012). Financial performance and predicting the risk of bankruptcy: a case of selected cement companies in India. International Journal of Public Administration and Management Research, Vol. 1, No. 1, Pages 40-56, October.

Ward, T. J., Foster, B., Woodroof, J. (2006). Estimated operating cash flow, reported cash flow from operating activities, and financial distress. Advances in Quantitative Analysis of Finance and Accounting, Vol. 4, Pages. 97-120. 